\title{
OĞUZ KAĞAN DESTANI'NDA HÜKÜMDAR TASARIMI
}

\section{Yasemin KURTLU* \\ Büşra KOÇAK ${ }^{* *}$}

\begin{abstract}
$\ddot{O} z$
Toplumdan millete geçiş ve devlet olma sürecinde kültürel birikim, hazırlayıcı etkisinin yanında sonucun yansıması bakımından da önemli bilgiler içermektedir. Kültürel birikimde, milletlerin tarihî gelişim sürecinde geçirdiği evreler simgesel veya doğal bir dille yer almaktadır. Sözlü veya yazılı edebî ürünler ise zengin bilgi kaynaklarının başında gelmektedir. Özellikle sözlü edebî ürünler tarihsel geçmişe 1şı tutan millet hafizası gibidir. Başka bir ifadeyle milletin hafizası sözlü kültür unsurlarıyla sonraki nesillere aktarılmıştır. Türk edebiyatının en eski örneklerinden biri olması nedeniyle Oğuz Kağan Destanı Türk kültürünün en eski izlerinin görüldüğü bir eserdir. Türklerdeki sosyal hayat, din, düşünüş, hükümdarlık anlayıș1, devlet felsefesi gibi daha birçok kültürel kodu bu eserde bulmak mümkündür. Dolayısıyla geçmişi bilmek, anlamak ve geleceğe yöntem önermek için söz konusu eser birçok bilimsel çalışmanın nesnesi olmuştur. Bu çalışmada Oğuz Kağan Destanı "hükümdar" tasarımı ve Türk tarih ve kültürü bağlamında bir hükümdarda bulunması gereken özellikler açısından incelenmeye çalışılmıştır.
\end{abstract}

Anahtar Sözcükler: Destan, Oğuz Kağan, hükümdar, tasarım.

\section{EMPEROR DESIGN IN THE EPIC OF OĞUZ KAĞAN}

\begin{abstract}
In the process of the transition from society to community and statehood, cultural richness contains important information in terms of the reflection of the result besides its preparatory effect. In cultural richness, the phases that the peoples experienced throughout the history take place symbolically or in a natural language. Written or oral literature pieces are primary rich information sources. Particularly the oral literature pieces are like peoples' memory that enlighten the historic past. In other words, the memory of a people has been transferred to the next generation with oral culture. As one of the oldest examples in Turkish literature, the Epic of Oğuz Kağan is one of the pieces in which the oldest marks of Turkish culture can be seen. To know and understand the past and to make proposals concerning the future, the mentioned piece has been the object of many scientific work. It is possible to find many cultural code such as social life, religion, mentality, management, state philosophy, etc. in Turkish in this piece. In this study, the Epic of Oğuz Kağan was analyzed in terms of the characteristics that an emperor should have in the context of Turkish history and culture. In the study, it was seen that the characteristics that are expected to be in a manager according to Turkish perception of state were all on the protagonist of the epic.
\end{abstract}

Keywords: Epic, Oğuz Kağan, emperor, design.

\footnotetext{
* Öğretmen, y.kurtlu@windowslive.com.

** Arş. Gör.; Ağrı İbrahim Çeçen Üniversitesi Eğitim Fakültesi Sınıf Öğretmenliği Bölümü, busrakocak2504@gmail.com.
} 


\section{Giriş}

Destanlar bir milletin ortaya koyduğu ilk edebî ürünlerdendir. Sözlü edebiyatın en güzel örnekleri ve geçmişin izlerini yansıtan kültür hazineleridir. Destanlar bir milletin elem ve kederleriyle; sevinç ve coşkularıyla bütün duygu ve düşüncelerini; millet olma yolundaki çabalarını ve bu çabalardan doğan ve taze tutulması istenen hatıralarını; geleceğe yönelik emellerini derleyip toplayan zengin edebî hazinelerdir. Destanlar bir milleti millet yapan bütün unsurları, kültür ve medeniyet çizgilerini, diğer kültürlerle alışverişi, bu alışverişin sınırlarını, üstünlük ve tesir sahalarını tespit etme imkânı sunan edebî türlerdir (Sepetçioğlu, 1972). Geçmişin izini sürmede destanlar genç nesillerin kılavuzu olmakta ve geçmişin kültürel birikimini günümüze taşımakta bir kod işlevi görmektedir. Bu kodların çözümlenmesiyle geçmişe bir pencere açılmaktadır. Böylece destanlarla daha yazının işlevsel olarak kullanılmadığı karanlık dönemlerle ilgili bilgiler edinilmektedir.

Türk edebiyatında yazılı dönemler takip edildiğinde destan kelimesinin dilimize, İslâmiyet'in kabulünden sonra "efsane, mesel, hikâyet-i güzeştegân" anlamında kullanılan Farsça kökenli “dâstân” kelimesinin ses ve anlam değişikli ile girdiği görülmektedir. Batı dillerinde ise Türkçedeki kahramanlık temalı ve olağanüstü motifli halk anlatıları olan "destan" terimine karşıll1lk olarak, çok yaygın olarak "epope", "epos" ve "epic" gibi terimler kullanılmaktadır (Oğuz, 2004). Destan kelimesinin Türk destan geleneği içerisinde tarihî seyrinden çok destan olarak tarihî süreçte şekillenen metinlerin tahlilinin daha isabetli olduğu düşünülmektedir.

Destanlar sözlü geleneğe bağlı nazım şeklinde ortaya çıkan, zaman ve mekân içinde toplumun iradesini yöneten kahraman-bilge şahsiyetlerin menkıbevi ve hakiki hayatları etrafında şekillenen öğretici halk edebiyatı ürünlerinin en eskilerindendir (Elçin, 1986). Milletlerin din, fazilet ve milli kahramanlık maceralarının manzum hikâyeleri olan destanlar, halk gözüyle görülen, halk ruhuyla duyulan ve halk hayalinde masallaştırılan tarihlerdir. Milletlerin dinleri, inanışları, yaşadıkları coğrafyanın özellikleri ile birleşmiş duygu ve düşünceleri destanlarda görülür (Banarl1, 2004). Destanlarda mitsel unsurlar ya da bir milleti derinden etkileyen olaylar ele alınır. Ele alınan bu konular ne tamamen gerçek ne de tamamen olağanüstü bir şekilde anlatılır. Destan kahramanları da sahip oldukları olağanüstü özellikleriyle içinden çıktıkları toplumların idealize edilmiş tipleridir. $\mathrm{Bu}$ nedenle hem fiziki hem de psikolojik bakımdan farklı özellikler gösterirler. Ancak destan kahramanlarına yüklenen bu özellikler çoğu zaman sembolik şekilde ifade edilir (Duymaz, 2007). Destanlardaki bu 
olağanüstü özellikler ve olaylar ise genelde kutsi bir boyuta sahiptir. Bu motifler ve sembolik anlatımlar bütünü ile bir toplumun yaşantısına yön verecek güçtedirler. Ayrıca destanlardaki doğaüstü motifler maddi ve manevi açıdan millilik gösterir (Öztürk, 1980). Dolayısıyla destan kahramanları üzerinden ortaya konulan özellikler destanın ortaya çıktığı toplum yapısını yansitmaktadır.

Özetle destanlar bütün bir milletin kültür birikimini yansıtan, sözlü edebiyat döneminin tarihî kahramanlık hikâyelerinin ve milletlerin var olma mücadelelerinin manzum bir dille anlatıldı̆̆ 1 kültür unsurlarıdır. Destanlarda sadece yaşamış bir kahraman değil aynı zamanda millet hafızasında idealize edilen tipler de yer almaktadır. Olağanüstü unsurlarla süslü, yalın bir dille ve simgesel anlatımla destanlar, toplumların hedeflediği insan tipinin, devlet yapısının ve felsefesinin ortaya konulduğu metinlerdir.

\section{Oğuz Kağan Destanı}

Türk milleti tarihî gelişim sürecinde millî benliklerinin imzasını taşıyan destanlar meydana getirmiştir. Bu türün en önemlilerinden biri Oğuz Kağan Destanı'dır. Oğuz Kağan Destanı'nın günümüzde iki varyantı vardır. Bunlardan biri İslam öncesinde Uygur yazısı ile yazılmış olan Paris Milli Kütüphanesi'nde bulunan, eksik tek yazma nüshadır. Bu nüsha ilk olarak Rıza Nur tarafından keşfedilmiştir. 1932 yılında W. Bang ve R. Rahmeti tarafından Almanca olarak yayımlanmış, daha sonra 1936 yılında Oğuz Kağan Destanı adıyla Türkçe olarak yayımlanmıştır (Bars, 2008). Uygur yazmasında baş ve son kısımlar eksiktir. Bu, destanın daha geniş olduğunun işaretidir. Kabaklı da (2006) Oğuz Kağan Destanı'nın bütününün elde mevcut olmadığını ifade etmektedir. Oğuz Kağan Destanı ile ilgili yapılan çalışmalarda oluşan ortak kanaat bu destanın Dede Korkut'a kadar uzanan devasa bir epiğin parçası olduğudur (Özarslan, 1998). Destanın diğer nüshası ise XIV. yüzyılda Reşideddin'in yazıya geçirdiği eserdir. Bu metin Z. Velidi Togan tarafından "Oğuz Destanı Reşidüddin Oğuznâmesi Terceme ve Tahlili” adıyla 1972 yılında yayımlanmıştır (Aksoy, 2000).

Destanın Uygur yazmasında işlenen konuların başında Oğuz Kağan'ın cihan fethini gerçekleştirme arzusu gelmektedir. Bu eser, eksik olmasına rağmen çok değerli bilgiler içermekte ve Türk dinî hayatına, göçebe hayat tarzına, hâkimiyet anlayışına ve dünyayı algılama biçimine 1şık tutmaktadır (Onay, 2013).

Destan kahramanına ilişkin de farklı rivayetler mevcuttur. Destanda adı geçen Oğuz Kağan'ın gerçek şahsiyeti ile ilgili düşüncelerden biri onun büyük Türk hakanı Mete olduğu 
yönündedir (Banarlı, 1987). Mete MÖ 209-174 yılları arasında Kuzeydoğu Asya'da kurulmuş Türk devletini büyük bir imparatorluk hâline getirmiştir. Ülkenin sınırları Çin'den Hazar Denizi’ne kadar bütün Kuzey Asya’ya yayılmıştır. Bu dönemde Mete yani Oğuz Han Çin’i de hükmü altına almayı başarmıştır (Yılbır, 2006).

Fakat Mete, fetihlerinde Orta Asya'nın dışına pek fazla çıkmamış, özellikle batıda Aral Gölü'nü aşmamıştır. Hâlbuki destandaki Oğuz Kağan, Orta Asya dışında Çin, Slav, Roma, Mısır ve Hindistan gibi büyük ülkeler fethetmiş bir hükümdardır. Bu durumda Türklerin Mete'den çok önce, yani İskit (Saka) çağında yaşamış ve dünya fethini gerçekleştirmiş büyük bir hükümdar olduğu da akla gelmektedir. Öyle ise destanın çekirdeği büyük ihtimalle bu hükümdar zamanında atılmış, bu çekirdeğin üzerine de Mete'nin hayat ve faaliyetleri eklenmiştir. Ayrıca destanda Hun, Göktürk ve Uygurlara ait unsurlar dikkat çekmektedir. Örneğin, Oğuz Kağan'ın bilge danışmanı "Uluğ Türük (Türk)” ile “kurt motifi”, Göktürkleri temsil eden birer kültür unsurudur (Koca, 2011). Bu bilgilerden hareketle destan kahramanı olarak ileri sürülen Mete Han'ın tek bir şahsiyeti temsil etmediği düşüncesi ortaya çıkmaktadır. Destanın bu açıdan da incelenmesi gerekebilir.

Yine Oğuz Kağan'ın kimliğine ilişkin dikkat çeken bir açıklamayı Gömeç (2004) yapmaktadır. Ona göre Oğuz Kağan, Büyük Hun Devleti’nin hakanı olan Mo-tun Yabgu'dur. Kendisini tahta varis göstermeyen babasını bir sürek avında öldürterek onun yerine geçen ve devlet teşkilatını düzenleyen Mo-tun Yabgu Orta Asya'da Türk birliğini gerçekleştirmesi ve Çin'i vergiye bağlamasıyla Türk tarihinde önemli bir yer edinmiştir. Gömeç'e (2004) göre böyle bir kimliğin Oğuz Kağan Destanı'ndaki Oğuz Kağan kimliğine esin olması muhtemeldir. O, görüşünü Mo-tun Yabgu'nun oğlu ve torunun (Kök ve Kün) isimleriyle Oğuz Kağan'ın çocuklarının isimlerinin benzerliği üzerinden temellendirmektedir. Yine Mo-tun Yabgu'nun babasını öldürerek tahta geçmesi Oğuz Kağan Destanı'nın Z. Velidi Togan'ın “Oğuz Destanı Reşidüddin Oğuznâmesi Terceme ve Tahlili” başlığıyla yayımladığı nüshaya göre Oğuz Kağan'ın babası Kara Han'ı öldürmesi (Kaplan, 2002) benzer görülmektedir. Reşideddin tarafından yazıya geçirilen Oğuz Kağan Destanı'nda yer alan Oğuz kağanlarından Tümen (Tuman) ismiyle Mo-tun Yabgu'nun babasının Tümen (Tu-man) (İnan, 1968) benzerliği de yukarıdaki görüşün ortaya atılan dayanaklarından biridir. Gömeç’e (2006) göre Oğuz Kağan'ın peygamber olma ihtimali de bulunmaktadır. Oğuz Kağan kişiliğine ilişkin birçok inceleme yapılmış ve çeşitli görüşler öne sürülmüştür. Ancak bu araştırmanın temel amacının dışında olduğu için konu burada detaylandırılmamıştır. 
Özetle Oğuz Kağan Destanı, Türk tarih ve kültürünün çok eski çağlarından bugününe kadar 1şık tutan; Türk düşünce sistemi, yaşantısı, mücadelesi ve ideallerini kuşaklara aktaran ölmez bir eserdir. Destan tarihî özelliğe sahip olduğu kadar bedii; mitolojik olduğu kadar da gerçek bir abidedir (Bayat, 2002).

\section{Türklerde Hâkimiyet Algısı ve Hükümdarlık}

Türkler tarih sahnesine çıkışlarıyla birlikte birçok devlet kurmuş ve devlet geleneklerini kesintisiz bir şekilde sürdürmüşlerdir. Türklerin kurdukları devletler daha çok Orta Asya coğrafyasında yoğunlaşmaktadır. Kurulan bu devletler içinde en ünlü olanı Mete Han tarafından kurulan Asya Hun Devleti'dir. Yazılı tarihî belgeler Türklerin devletleşme sürecini Mete Han ile başlatmaktadır. Asya Hun Devleti siyasi ve askeri teşkilatlanmanın ilk örneği olarak kabul edilmektedir. Mete Han'ın en büyük başarısı ise Orta Asya ve Türk kavimlerini bir araya getirmiş olmasıdır. Ayrıca Mete Han, millet olma bilincini de beraberindeki Türk topluluklarına aşılamıştır.

Hun Devleti’nde devleti yöneten kişiye "Tengri Kut” unvanı verilmiştir ve hükümdarlık bir sülalenin elinde irsidir. Tengri Kut, bütün orduların başkumandanıdır ve bütün yüksek memurları o tayin etmekle yetkilidir. Devletin başındaki yöneticinin asil bir soydan geldiği anlayışı da yine Türklerde hâkimdir. Liderini yüceltmek Türk toplumunun en önemli özelliklerindendir. Ayrıca devleti idare eden yönetici, topraklarını genişletmekle de yükümlüdür. Ziya Gökalp'e göre “Tudunluk” durumda bir Türk devleti kurulduğunda, onun az zamanda "İlhanlığa"çıkması mümkündür. Türk devleti bir merdiven gibidir ve onun ilk basamağına çıkan ya inecek ya da en son basamağa kadar yükselecektir. Hun, Göktürk, Uygur, Karahanlı, Gazneli ve Selçuklu devletlerinde bu özellik görülmektedir (Akyüz, 2002).

Türk devletlerinin bir diğer özelliği ise kesintisiz bir şekilde tarihteki varlığını devam ettirmiş olmalarıdır. Nitekim tarihî süreç göz önüne alındığında Türk devletlerinden biri yıkılsa da akabinde ya da aynı dönemlerde başka Türk devletlerinin varlık gösterdiği görülmektedir. $\mathrm{Bu}$ durum Türklerdeki varlığı devam ettirme ve devlet anlayışının da bir göstergesidir. Köklü devlet şuuru, Türk devletlerinin değişmeyen niteliklerinden biridir. Devlet, Türk medeniyetinin temel unsurlarındandır. Hür ve bağımsız devletin egemenliği altında yaşamak Türk milletinin var olma şartıdır (Kazmaz, 2000).

Türklerde cihan hâkimiyeti ülküsünün varllğından da bahsetmek mümkündür. Nitekim ilk siyasi belge kabul edilen Orhun Kitabeleri'nde de Türklerin bu ülküsüne değinilmektedir. 
Dokuz Oğuz beyleri, milleti! Bu sözümü iyice işit, adamakıllı dinle. Doğuda gün doğusuna, güneyde gün ortasına, batıda gün batısına, kuzeyde gece ortasına kadar, onun içindeki millet hep bana tabidir. Bunca milleti hep düzene soktum. O şimdi kötü değildir. Türk kağanı Ötüken ormanında oturursa ilde sıkıntı yoktur (Ergin, 2011, s. 3).

Kaşgarlı Mahmut Divanü Lügat-it Türk adlı eserinde Türklerin cihan hâkimiyeti düşüncesiyle ile ilgili şunları yazar:

Tanrı'nın devlet güneşini Türk burçlarında doğdurmuş olduğunu ve onların mülkleri üzerinde göklerin bütün teğrelerini döndürmüş bulunduğunu gördüm. Tanrı onlara Türk adını verdi ve onları yeryüzüne ilbay kıldı. Zamanımızın hakanlarını onlardan çıkardı; dünya milletlerinin idare yularını onların ellerine verdi; onları herkese üstün eyledi; kendilerini hak üzere kuvvetlendirdi. Onlarla birlikte çalışan onlardan yana olanları aziz kıldı ve Türkler yüzünden onları her dileklerine eriştirdi; bu kimseleri kötülerin, ayak takımının şerrinden korudu (Kaşgarlı Mahmut, 1991'den akt. Kazmaz, 2000, s. 129).

Tarihin hiç bir döneminde devletsiz kalmayan Türkler; sadece Orta Asya'nın tümüne hükmeden devletler kurmamış, üstün teşkilatçı özellikleri sayesinde zaman zaman Orta Asya'nın da dışına taşarak yeni siyasi yapılar oluşturmuşlardır. Türkler, devletin; millî varlığını koruyan, yaşatan ve geliştiren vazgeçilmez bir kurum olduğunun daima farkında ve bilincinde olmuşlardır.

\subsection{Türklerde "Kut" Anlayışı}

Türk hâkimiyet anlayışına göre, Türk hükümdarlarına hâkimiyet yetkisi Tanrı tarafından verilmektedir. Türk hükümdarı Tanrı tarafından kendisine verilen bu yetkiyle halkını yönetir. Yani siyasi iktidarının kaynağı kendisine "kut" veren Tanrı'dır ve hâkimiyetinin dayană̆ı ilahidir. Bu açıdan Türk hükümdarı adeta gögün yeryüzündeki temsilcisi gibidir. Bu hâkimiyet anlayışının Asya Hun Devleti döneminden itibaren Türk devlet anlayışının temelini oluşturduğu görülmektedir (Tuğral, 2008). Kut anlayışını Jean-Poul Roux (1999, s. 36) "Çadırın açıklığından düşen jelatinimsi madde, zihin, ruh, hayati güç, şans, sürüleri koruyan bir muska veya nazarlık" şeklinde açıklamıştır.

Eski Türklerde "kut" kelimesine şu anlamlar verilmiştir: 1) can, ruh; 2) baht, uğur, başarı, rızık; 3) yücelik, mertebe; 4) gerçeğe ulaşmak, aydınlanmak, 5) sevinç (Kazakistan Ulttıq Entsiklopediyas1, 2004, s. 149'dan akt. Bogenbayev ve Calmırza, 2014, s. 70). 
Büyük Türk hakanı Mete Han’ın unvanı, “Tanrıkut Bagatur Han”dır. Yani Tanrı'nın kutsadığı yiğit hükümdar anlamına gelmektedir. Göktürk Kağanı Bilge Kağan ise "Tanrı'dan olmuş ve Tanrı'ya benzer Türk Bilge Kağan" ifadeleriyle tanımlanmıştır. Bu ve benzer ifadelerle bizzat Tanrı tarafindan görevlendirildiğine inanılan hakanın yöneticilik yetkisi babadan oğula irsi olarak geçmektedir. Hanedan, insanüstü nitelikleriyle her şeyin odağında yer alır (Akyüz, 2002).

Ziya Gökalp'e göre, Kut, Şamanizm'in kalıntısı ve "ruh”tur. Klan hâlinde yaşayan ilkel topluluklarda "mânâ" denilen esrarlı ruhun aynıdır. Kaşgarlı Mahmud "kut" tabirine "devlet" anlamını vermiştir. Kutadgu Bilig'in isminde de bulunan "kutadgu" ibaresi, kutadmak fiilinden yapılmış masdar olup, kut'a eriştirmek, kut sahibi kılmak demektir. Kut, Tanrı'nın vermiş olduğu bir lütuf ve keremdir; talih ve rastlantı değildir. Sonucu ise başarı olarak görülür. XI. yy'da Kaşgarlı Mahmud kut'u, devlet olarak ele almıştır. Devletli olan, ikbâl ve saadet sahibi olmalıdır. Ancak o günkü saadet sözü bugünkü mesut olmak ile aynı anlamı karşılamamaktadır. Kut ve kutluluk; halkın anlayışı ile bir devlet kuşu gibidir (Ögel, 1982).

MÖ II-I. yüzyıllarda Hunların kağanları "kut” kelimesini “tengri kutı” şeklinde bizzat unvanlarında kullanmışlar ve bu kelimeyi Türklerin temas ettiği dinler dahi ortadan kaldıramamıştır. İslamiyet'in kabulüyle "kut", "talih, baht, saadet" anlamlarına gelmişse de, İslam'dan önceki manası ve ifade ettiği dinî kült XI. asırdan sonra İslâm edebiyatında da pek çok yerde kullanılmıştır (İnan, 1970).

Türk hâkimiyet düşüncesine göre Tanrı sadece siyasi iktidarı veren değil, aynı zamanda vermiş olduğu bu iktidarı geri alabilen bir kudrete sahiptir. Tanrı'nın bu kuvveti, Türk hükümdarlarının üzerinde daima siyasi bir baskı aracı olmuştur. Bu nedenle Türk hükümdarları Tanrı'nın verdiği "kut”u ellerinde tutabilmek için devamlı çalışmak ve başarılı olmak zorundadır. Hükümdarlığı hak ettikleri sürece başta kalır aksi takdirde kutlarını kaybederek iktidardan düşerler (Koca, 2002).

Kut'un kalıcı olması için hükümdarın akıl, bilgi, iyi huy, alp ve cihangir olma, erdem sahibi olma gibi özelliklerin yanında; iyilik, güç, alçak gönüllü ve tatlı dilli olma, aşırı olmayıp kötü işlere girmeme, malını yerinde harcama, büyüğe saygı ve küçüğe sevgi gösterme, kimseyi kırmama, içki ve israftan uzak durarak dürüst olma gibi özellikleri taşıması gerekir (Ögel, 1982). 
İslamiyet öncesi dönemde hâkim olan kut anlayışı, İslamiyet sonrası dönemdeki Türk toplumunda da görülür. Kutadgu Bilig'de de İslami bir biçimde "kut" ifade edilmeye çalışılır. Egemenlik hakkı ve yönetme yetkisi "bey" e aittir. Bu hak ve yetki doğuştan kazanılmıştır ve kalıtsal olarak babadan oğula geçer. Çünkü beyden bey doğar. Beye üstünlük vasfı Tanrı tarafından verilmiştir. Hakanlık yetkisi doğuştandır. Yusuf Has Hacib kut yetkisinin verilmesini “nasip” olarak değerlendirmektedir (Akyüz, 2002).

$\mathrm{Bu}$ bilgilere göre Türk kağanları yeryüzünde Tanrı'nın temsilcisi olarak görev yapmakta, bu onun seçildiği anlamına gelmektedir. Kendine yüklenen vazifeleri en iyi şekilde yerine getirmekle görevli olan kağanlar maddî ve manevî birçok özelliğe de sahip olmaları gerekmektedir. Oğuz Kağan Destanı'nın ise bu manada zengin bir içeriğe sahip olduğu bilinmektedir ve anlatıdaki Oğuz karakteri de kut'a sahiptir. Ana kahramanın başarıları göksel unsurlarla ilişkilendirilerek verilmiş ve onun kağanlığı kut inancı gereği kutsanmıştır. Kısaca destanda Oğuz Kağan'ın hakanlığını güçlendirici ilahi bir dayanak olarak kut kavramının kullanıldığı görülmektedir.

\section{Oğuz Kağan Destanı’nda Hükümdar Tasviri}

Türk tarihinde Türk boylarının tek bir siyasal hâkimiyet altında toplandığı ve yaşadığı ilk ve en uzun dönemi kapsayan dönem Hun Devleti'dir. Türk kültür ve medeniyetinin kurucu ortak mitik hafızası ve kolektif bilincin bu dönemde başladığı söylenebilir. Bir Hun destanı olan Oğuz Kağan Destanı bu dönemin bir yansıması olarak kabul edilebilir (Çiftçi, 2013).

Oğuz Kağan Destanı, bize Türklerdeki yönetici anlayışı ile ilgili birtakım ipuçları vermektedir. Destan kahramanı olması nedeniyle Oğuz Kağan olağanüstü özellikler göstermektedir. Destan kahramanları olağanüstü nitelikleriyle toplumların ideal tipleridirler ve hem psikolojik hem de fiziki anlamda sıradan insanlardan daha farklı özelliklere sahiptirler. Destan kahramanına yüklenen bu olağanüstü nitelikler çoğunlukla çeşitli sembollerle ifade edilir. Uygurca Oğuz Kağan Destanı'nda Oğuz'un beden tasvirlerinde de bu sembolleri görmek mümkündür (Duymaz, 2007).

Oğuz Kağan Destanı “Günlerden bir gün Ay Kağan'1n gözü parladı. Erkek oğul doğurdu." (Banarl1, 1987, s. 17) ifadeleriyle başlar. Destandan hareketle öncelikle "Ay Kağan”ın sembolik bir anlam taşıdığı düşünülebilir. Burada asıl verilmek istenen mesaj Oğuz Kağan'ın "kut” taşıdığıdır. 
Türk inanç sisteminde çok önemli bir yere sahip olan ve bir ışık şeklinde cisimleştirilen kut, kağan ve hanlara Tanrı'nın bağışladığı bir ayrıcalıktır. Ayrıca “Ay Kağan” ifadesinden Oğuz Kağan'in mensup olduğu soyun özelliklerini belirlemek mümkündür. Türk devlet geleneğine göre "kut" ya da yöneticilik yetkisi bir sülalenin elinde irsidir ve Hun Devleti gücünü Tanrı'dan aldığına inanan aristokratik yapıda bir devlettir (Akyüz, 2002). Buradan hareketle Oğuz Kağan'ın ailesinin hanedanlığa mensup olduğu söylenebilir. Öte yandan Oğuz Kağan'ın kendisini “Uygurların Kağanı” olarak tanıtması ve annesinin adının "Ay Kağan” olması da Uygur döneminin etkisini göstermektedir. Zira Uygurlar, Maniheizme girmeleriyle "ay"a birinci derecede bir önem atfetmişlerdir. Hâlbuki eski Türk inancında "ay" değil, "gök ve gün (güneş)” birinci derecede bir öneme sahiptir (Koca, 2011).

Oğuz Kağan'ın doğumu ile ilgili olan ifadeyi retorik bir yaklaşımla metni tahlil ederek, Oğuz Kağan'ın dişi Ay ile erkek Boğa'nın birleşmesi sonucunda doğduğunu söyleyen Sencer Divitçioğlu, diğer dünya efsanelerinde Ay'ın dişi Boğa'nın erkek olduğundan hareketle, Ay Kağan ifadesinin yanlış okuma sonucu olduğu aslında kelimenin Han olabileceği ve bu kelimeden bayan unvanı Hanım şeklinde tercüme edilmesi gerektiği; dolayısıyla Ay Kağan'ın veya Ay Hanımın dişi olduğu fikrindedir. Yazar, Oğuz Kağan'ın doğumunu kendi deyimiyle Freudgil bir yaklaşımla şöyle okur: "Ay Hanımın matrisi yarılıp (kana) boyandı ve bir erkek çocuk doğurdu" Boğa ve Ay ongunlarından olan çocuğun doğumdan sonra olağanüstü olması da kaçınılmazdır. Bu duruma göre Oğuz Kağan'ın ataları ilahi güç taşırlar. Dolayısıyla kahramanda da ilahi güçlerin bulunması söz konusudur. Oğuz Kağan bu vasıflarıyla toplum için ideal insan tipindedir (Özarslan, 1998, s. 434).

Bayat (2002) eski Türk inanışında boynuzun güç, hâkimiyet sembolü olduğunu ve boynuzun Ay kültüyle ilgili olduğunu, Oğuz Kağan Destanı'nda, Oğuz Kağan'ın annesi Ay Kağan'ın ise Ay Tanrı inancının bir yansıması olduğunu ifade etmiştir. Destanda Oğuz Kağan'ın ayağının boğa ayağına benzetilmesiyle de boynuz ay ilişkisinin yansıtıldığını söylemiştir. Nitekim mavi renkli boğanın gölün, kara renkli boğanın yerin veya Altay’ın sahibi olduğunu belirten Bayat (2002) Oğuz Kağan'’n eski mitolojik düşüncelerin eklemlenmesiyle Ay Tanrı'nın yerdeki simgesi olan boğayla eşleştirildiğini söylemiştir. Yine ona göre Ay Kağan, Oğuz Kağan'ın annesidir, destanın diğer kısımlarında da ondan bir daha söz edilmemiştir ve bu anlamda Freud'un yaklaşımının Oğuz Kağan Destanı için geçerli olmayacağını düşünmektedir (Bayat, 2009). 
Her iki görüşte Oğuz Kağan Destanı'nın iki farklı varyantı için ayrı ayrı ele alınabilir. Birinci görüşün Freud'un yaklaşımı temelinde düşünüldüğünde Reşideddin'in nüshası için geçerli olduğu söylenebilir. Ancak bu düşüncenin destanın Uygur nüshası için geçerli bir biçimbirim olarak kanıtının bulunmadığı da bir gerçektir. Simgesel bir çözümlemeye gidilecekse ve Oğuz Kağan'ın mücadele ettiği canavarın babasını temsil ettiği yorumları dikkate alınacaksa her iki nüsha için Freud yaklaşımı söz konusu olabilir.

"Bu oğlun yüzü gök rengi, ağzı ateş kızılı, gözleri ela, saçları ve kaşları kara idi. Güzel perilerden daha alımlıydı" (Banarlı, 1987, s. 17) ifadeleriyle Oğuz Kağan tasvir edilir. Tasvirde dikkat çeken 1şık, renk ve gökyüzü cisimlerinin adlarının kullanılmasıdır. Nitekim Türk mitinde 1şık, renk ve gökyüzü cisimlerinin sembolik anlamları oldukça geniştir.

Ögel (1982), yüzün eski Türklerde insanın en önemli yeri olduğunu ve bütün duygusal özelliklerin ve kutsallığın yüze aksettiğini, kötü insanların yüzünün kara, iyi insanların yüzünün ak ve kutsal insanların yüzünün ise gök rengi olduğunu belirtmiştir. Oğuz Kağan'ın yüzünün gök rengi olmasının onun gökten geldiğine, Tanrı'nın rengini taşıdığına inanılması olduğunu söylemiş̧ir. Daha sonraki Türklerde de gök renginin olgunluk, erginlik ve tecrübenin bir sembolü olarak görüldüğünü vurgulamıştır. "Beyaz, siyah ve mavinin özel bir anlamı olan Kazaklarda kara renk soğuğu, rahatsızlı̆̆ı, ağır başlılı̆̆ı; kırmızı ateşi, sıcaklığı; yeşil diriliği, gençliği; beyaz temizliği, saflığı; mavi göğe bağlı inanc1, ebedîliği ve uzun yaşamı simgeler" (Kadaşeva, 1996, s. 95'ten akt: Küçük, 2010, s. 195).

Oğuz'un ağzı ateş renginde ve gözleri ise aldır. Kırmızı renk mitolojilerde güneşin ve savaş tanrılarının rengi olarak yer almaktadır. Kuvvet, güç, iktidar, hâkimiyet ifade eder (Çoruhlu, 2002). Küçük (2010), Oğuz Kağan'ın gözlerinin ela yani kırmızı olduğunu belirtmektedir. Oğuz Kağan'ın gözünün kırmızı olması alpliğinin işareti olarak kabul edilir. Anadolu'da çok eskiden beri kullanılan gözü kanlı deyimi "hiçbir şeyden yılmayan, hiçbir şeyden korkmayan atak, cesur kimse” manasına gelmektedir (Sertkaya, 1992; Küçük, 2010)

Oğuz'un da göğe ait bir kahraman olduğunu vurgulamak için onun yüz ve beden özelliklerinin göksel olanla benzerlik gösterdiği kullanılan bazı sembollerle belirtilmiştir. Âdeta Oğuz'un yüzünde gökyüzü sembolize edilmiştir. Onun göğün veya kutsalın oğlu olarak yeryüzüne indirildiği, Tanrı adına yeryüzünde kendisine verilen kızlarla insan neslini başlattığı destanda sembolik ifadelerle belirtilmiştir (Duymaz, 2007, s. 53). 
Öyleyse Oğuz Kağan'a doğumundan itibaren bahşedilmiş bir güç, iktidar ve hâkimiyetin; Türk töresine göre "kut"un verildiği söylenebilir.

Oğuz Kağan Destanı'nın devamında yeni doğan bir çocuğun gerçekleştirdiği davranışları çok süratle yapıp terk ettiği görülmektedir. Ayrıca bir çocuğun yapamayacağı çiğ et, çorba ve şarap istemek, dile gelmek ve kırk günden sonra yürüyüp oynamak gibi davranışlar destanın havasına uygun kullanımlardır. Burada asıl amaçlanan kendisine kut bahşedilmiş bir kişinin diğer insanlardan farklı olacağıdır. Oğuz, diğer çocuklar gibi değildir. Tanrı onu kutsal bir amaç için bu dünyaya göndermiştir. Oğuz’un “cihangir olma ideali”ni şiddetle hissetmesi, gücünü bu amaç için kullanması sürati sağlayan önemli bir husustur (Kaplan, 1986). Lord Raglan'ın geleneksel kahraman kalıbı açısından düşünüldüğünde Oğuz Kağan Destanı'nda Oğuz Kağan'ın çocukluğuyla ilgili destan metninin karakterine uygun olarak çok fazla bilgiye yer verilmediği söylenebilir. Ancak Lord Raglan'ın geleneksel kahraman kalıbının Türk kahraman kalıbına uygun olmadığını Çobanoğlu (1996) “Lord Raglan'ın Batı Halk Kahraman Kalıbı Açısından Oğuz Kağan ve Er Töştük Destan Kahramanlarına Bir Bakış” adlı çalışmasında ortaya koymuştur. Dolayısıyla bir milletin kendi kültür kodlarıyla şekillenmeyen bir kahraman kalıbıyla millî duyuşun müşahhas ürünü olan destan kahramanlarını yorumlamanın ne derece isabetli veriler ortaya çıkaracağı tartışılabilir.

Metnin devamında Oğuz Kağan'ın beden tasviriyle ilgili şu özelliklere değinilmektedir: “Ayakları öküz ayağı gibi, beli kurt beli gibi, omuzları samur omuzu gibi, göğsü ayı göğsü gibi idi. Vücudunun her yeri tüylü idi” (Banarl1, 1987, s. 17-18). Bu tasvirde kullanılan hayvanlar fiziki gücü, vücut kuvvetini en üst düzeyde yansıtabilen hayvanlardır. Ayak gücünde öküz, belin sağlamlığı ve çevikliğinde kurt, omuzda samur ve göğüste ayı kullanılmıştır.

Oğuz Kağan'ın belinin kurt beline benzetilmesi de onun sırım gibi güçlü bir bedene sahip olduğunu anlatmak için yapılmıştır... Oğuz Kağan'ın göğsünün ayıya benzetilmesi onun fiziki yapısının heybetli, vücudunun kıllı ve güçlü olduğunu anlatmaktadır... Oğuz Kağan'ın omuzları samura benzetilmesiyle hem geniş omuzluluğu hem de tüylü omuza sahip olduğunu anlatılmak istenmiştir (Güven, 2009, s. 84- 89).

Duymaz’a göre (2007) tabiattaki hayvan özelliklerinin insana aktarılması gerçek bir tasvir olarak değerlendirilemez. Bu benzetmeler Oğuz Kağan'ın tabiatla başa çıkabilmesi için sembolik olarak kullanılmış ve Tanrı'dan alınan kut ve sembollerle ifade edilen güç ile Oğuz'un 
kağan olacağı anlatılmıştır. Yine Oğuz Kağan tanrısal modeli yeryüzünde oluşturmaya memurdur ve görevini de dünyayı örgütleyerek yapabilecektir.

Oğuz Kağan Destanı'nda Oğuz Kağan'ın doğumunun mitolojik bağlamla ilgili olduğu ve mitolojik bağlam içinde takdim edildiği görülmektedir. Onun gözlerinin ala, yüzünün mavi, ağzının kırmızı oluşu da mitolojik metinlerin özelliğinin bir yansıması olarak Tanrığlu sıfatı gereği kullanıldığ1 görülmektedir. Oğuz Kağan'ın dış görünüşündeki hayvan simgelerinin kullanılmasıyla onun Tanrığlu motifi kuvvetlendirilmiştir. Oğuz Kağan'ın tasvirinde hayvan motiflerinin (Kurt, boğa) kullanılması Türk mitoloji sisteminde türeyişle ilgili toplum hafızasının yansıması olduğu yorumu yapılabilir (Bayat, 2006).

Destan metninin devamında Oğuz Kağan'ın at sürüleri güttüğü, ata bindiği ve av avladığı, günlerden ve gecelerden sonra ise yiğit olduğu belirtilmektedir (Banarl1, 1987). Oğuz Kağan'ın sahip olduğu bu özellikler onun göçebe bir toplumda yaşadığını göstermektedir. Göçebe Türk topluluklarında erkeklerin at sürüleri gütme, ata binme, av avlama gibi sorumlulukları vardır. Bu özellikler Oğuz Kağan'ın şahsiyetinde savaşçı bir kimliğin de oluşmaya başladığını göstermektedir.

Göçebe Türk topluluklarında at sürüleri gütme, ata binme, avcılık gibi faaliyetlerle Türk insanı her türlü yaşam şartına dayanabilecek ve uyum sağlayacak şekilde sağlam bir vücut ve ruh yapısı kazanmaktadır. Oğuz Kağan da gençlik çağına erişirken avcılık yapıp, at sürüsü besleyip, akın faaliyetlerinde bulunarak bedenen ve ruhen güçlü bir yiğit olmuştur (Koca, 2011).

"Bu çağda bu yerde bir ulu orman vardı. Çok dereler, çok ırmaklar var idi. Buraya gelen avlar çok çok, burada uçan kuşlar çok çoktu" (Banarlı, 1987, s. 18). Destanda geçen "ulu orman", "çok dereler ve çok irmaklar" ifadelerinden yola çıkarak metinde bahsi geçen bu ormanın Ötüken Ormanı olduğu söylenebilir.

Ötüken bölgesinde başlıca üç ırmak vardır. Bunlardan Orhun Irmağı, şehrin güneyine bitişik dağlardan çıkıp kuzey-doğuya doğru, Tamır Irmağı, şehrin batısından geçerek kuzeye doğru, Kurban Tamır Irmağı ise kuzey doğuya doğru akardı. Bu ırmakların her üçü de, başkentin yaklaşık 48 km (30 mil) kadar kuzeyinde bulunan bir yerde birleşerek büyük Selenga nehrini oluştururdu. Orhun ve Tamır ırmaklarının baş kısımları, Türklerin ve hattâ bütün Orta Asya halklarının en kutsal yeri sayılan Ötüken bölgesini çeviriyordu... Orhun ırmağının kaynağına yakın yerdeki Ötüken yöresi anlaşıldığına göre, sulak, çayırlık, her bakımdan hoş bir yerdi (Aydemir, 2010, s. 198). 
Ötüken iktisadi ve stratejik konumu itibariyle Hun, Birinci ve İkinci Göktürk Devleti ve Uygur Devleti'ne başkentlik yapmıştır. Orhun Abideleri'nde de “Ötüken yerinde oturup kervan, kafile gönderirsen hiçbir sıkıntın yoktur. Ötüken ormanında oturursan ebediyen il tutarak oturacaksın" (Ergin, 2011, s. 5) ifadelerine yer verilmiştir.

Yazıtların ifadesinden anlaşıldığına göre Ötüken cihanın bir merkeziydi. Bir cihan devleti olma amacında olan Türk devletinin merkezi de cihanı merkezinde olmalıydı. Dolayısıyla Orta Asya'yı hâkimiyeti altına alan bir devlet başkent olarak Ötüken'i seçmek zorundaydı. Çünkü burası kutsal bir yerdi. Tanrı'nın dünyaya, dünyanın da Tanrı'ya en yakın olduğu yer burasıydı. Orta Asya egemenliği ancak bu görevi yerine getirmekle tamamlanabilirdi (Aydemir, 2010, s. 200).

Destanın devamında Oğuz Kağan ormanda yaşayan ve halkı ağır baskılarla ezen, sürülerini ve halkı yiyen büyük bir canavarla savaşır ve onu alt eder.

Bu ormanın içinde büyük bir canavar var idi. At sürülerini ve halkı yerdi. Büyük, yaman bir canavardı. Ağır bir baskı ile halkı ezmişti. Oğuz Kağan bir yiğit, cesur kişi idi. Bu canavarı avlamak diledi. Günlerden bir gün ava çıktı. Çıda ile ok-yay ile, kılıç ve kalkanla atlandı. Bir geyik yakaladı. Bu geyiği, dalın çubuğu ile bir ağaca bağladı. Gitti. Ondan sonra sabah oldu. Tan ağaran çağda geldi, gördü ki canavar geyiği almıştır. Gene bir ayı tuttu. Altınlı bel bağı ile ağaca bağladı. Gitti. Bundan sonra sabah oldu. Tan ağaran çağda geldi, gördü ki canavar ayıyı da almıştı. Bu sefer ağacın dibinde (kendisi)durdu. Canavar gelip başı ile Oğuz'un kalkanına vurdu. Oğuz çıda ile canavarın başına vurdu. Onu öldürdü. Kılıç ile başını kesti, aldı gitti. Gene gelip gördü ki, bir sunkar (ala doğan) canavarın içerisini (bağırsaklarını )yemektedir. Yay ile ok ile o sunkarı öldürdü. Başını kesti. Ondan sonra dedi ki: Canavar geyik yedi, ayı yedi, çıdam (onu) öldürdü. Demir olduğundandır. Canavarı sunkar yedi. Yayım, okum öldürdü. Bakır olduğundandır, dedi ve gitti (Banarlı, 1987, s. 18).

Türklerdeki hâkimiyet anlayışında tahta çıkmaya hak kazanan kişi Tanrı'nın seçtiği kendisine güç, kuvvet bahşettiği kişidir. Hükümdarlık ise hanedan üyeleri arasında kan yolu ile geçerdi. Tahta çıkacak üyenin seçiminde Tanrı, takdirini hanedanın en yetenekli ve tahtın hakkını verebilecek üyesi için kullanmaktaydı. Tanrı, seçimini dolaylı yoldan işaret etmek suretiyle belli ederdi. Tanrı'nın hangi üyeyi işaret ettiği ise taht için yapılan mücadelenin sonunda ortaya çıkardı. Dolayısıyla Eski Türk devletlerinde hanedan üyelerinin çatışması kaçınılmaz olmuştur. Hükümdarın hayatta iken veliaht tayin etmesi dâhi mücadeleyi 
engellememiştir. Diğer hanedan üyeleri, taht üzerinde hak sahibi olduklarını ve tahttan feragat etmeyeceklerini söyleyerek taht mücadelesine başlarlardı. Yeni hükümdarın hâkimiyetini güçlendirip pekiştirmesi ise kanlı bir iktidar mücadelesi sonucu gerçekleşirdi. Tüm bu mücadelelerin Tanrı'nın işareti ile başladığını düşünen halk, taht mücadelelerini meşru görmüştür. Nitekim Hun hükümdarı Mete de tahta çıkmak için babasına karşı mücadele vermiştir. Hun veraset sistemine göre, Tuman'ın tahtına Ulu Hatunun oğlu Mete'nin halef olması gerekirken, Tuman tahta Mete yerine annesi Çinli olan küçük oğlunu oturtmak istemiştir. Ancak, tahta çıkmak isteyen Mete, babasına karşı gelmiş ve onu öldürerek M.Ö. 209 yılında hükümdar olmuştur. Hunlar Mete’yi babası ile mücadelesinden sonra hükümdar olarak kabul etmişlerdir (Koçak, 2011).

Türk töresine göre hakan olma hakkı büyük oğla aitti. Küçük oğul hâkimiyet için hak iddia edemezdi. Bunu değiştirmek isteyen ise örfü yıkmış sayılırdı. Bu yüzden Mete ve babası arasındaki mücadelede törenin ihlal edilmesi söz konusudur. Çünkü Mete'nin babası Tuman hâkimiyeti büyük oğluna vermeği istememektedir. Bu motif Oğuz Kağan Destanı'nda devleti idare etme kanununun ve varislik prensibinin bozulması şeklinde destana yansımaktadır (Bayat, 2009).

Koca'ya göre (2011) destandaki öğelerin sembolik değerleri göz önünde bulundurulduğunda ve destanda bahsi geçen efsanevi şahsiyetin Mete Han olduğu düşünüldüğünde burada geçen yabani hayvanın öldürülmesinin tarihî temelinin Mete'nin babasıyla mücadelesine dayandığı düşünülebilir. Mete Han babasını yenebilmek için önce kendisine bağlı bir tümen eğitmiş ve daha sonra babasını bir darbe ile bertaraf etmiştir. Buradaki mücadelenin baba oğul arasındaki mücadele olduğu ve metinde canavarın halkı ağır baskı ile ezdiği ifadeleri düşünüldüğünde Mete'nin babasının halka zulmettiği ve bu nedenle Mete'nin babasıyla mücadele ettiği söylenebilir. Yani babası "kut"u kaybetmiştir ve yönetim sırası oğlu Mete'ye geçmiştir.

Oğuz Kağan cesur ve yiğit bir kişidir. Aynı zamanda canavarı avlamak istediği için kendine güvenmektedir ve güven sahibidir. Yine ava giderken gerekli silahları almış bir plan ve hazırlık yapmıştır, sonra avının karşısına çıkmıştır. Dolayısıyla bunları planlamak ince bir zekâ ve düşünme eylemini gerektirir. Oğuz Kağan da akıllı, düşünen ve aklını kullanan bir kişiliktir. Oğuz Kağan'ın canavarla mücadelesinden onun kağan olmak için akli olgunluğa da sahip olduğu görülmektedir. Kağan olacak bireyin fiziksel gücün yanında akıl gücüne de sahip olmas1 gerektiğini düşünen toplumsal hafiza Oğuz Kağan'1 hem güç hem de düşünsel arka plan 
gerektiren bir sınava tabi tutmuş ve onu canavarla karşılaştırmıştır. Bu güçlüklerle mücadele edebilecek bir yöneticinin kağan olacağı anlatıda ifade edilen mesajlardandır.

Gene günlerden bir gün, Oğuz Kağan bir yerde Tanrı'ya yalvarmakta idi. Gökten bir gök ışık düştü... Gördü ki bu 1şığın arasında bir kız var... gülse Gök Tanrı da gülüyor; ağlasa Gök Tanrı da ağlıyor... Günlerden gecelerden sonra (kızın gözleri) parladı. Üç erkek oğul doğurdu. Birincisine Gün adını koydular. İkincisine Ay adını koydular. Üçüncüsüne Yıldız adını koydular... Gene bir gün Oğuz Kağan ava gitti. Bir göl ortasında, önünde bir ağaç gördü. Bu ağacın kovuğunda bir kız vardı... Onu sevdi, aldı. Günlerden sonra, gecelerden sonra (kızın gözü) 1şıldadı. Üç erkek oğul doğurdu. Birincisine Gök adını koydular. İkincisine Dağ adını koydular. Üçüncüsüne Deniz adı koydular (Banarlı, 2004, s. 18).

Metin incelendiğinde Oğuz Kağan'ın Tanrı'ya yalvardığı dile getiriliyor. Oğuz Kağan'ın eşlerinin biri gökten 1şık olarak indiriliyor, ikincisi gol ortasında ağaç kovuğunda karşısına çıkıyor. Metinde kullanılan simgesel anlatım Gök Tanrı inancının birer yansıması olarak yorumlanabilir. Ancak ilk olarak Oğuz Kağan'ın dinî inançlarını yaşadığı çıkarımında bulunulabilir. Yine birinci eşinin dua (yalvarma) sonrası gökten indirilmesi de dinî inanışın bir gereğidir. Kağan olan ve Gök yüzlü Oğuz Kağan'ın eşleri de onun gibi kutlu olmalı ve gökle bağlantılı olmalı inanışının olduğu söylenebilir.

Divitçioğlu (1994) Tanrıya yalvarma sonrasında ilahi özellikler taşıyan kızın gökten indirilmesini inanç sistemine bağlar ve bu kızın göğün kızı olduğu yorumunu yapar. Çünkü bu kızdan doğan çocuklar Gün, Ay ve Yıldız gögün sembolü olan unsurlardır ve Tanrı bu kızı döllenme imi olarak indirmiş ve Oğuz'a doğurganlık bahşetmiştir. Destanda Oğuz'un gökten inen ve ağaç kovuğunda bulunan kızla evlenmesi Türklerin varoluşla ilgili inanışlarının destana yansıması olarak da yorumlanabilir (Ercilasun, 2002).

... gökten inen 1şığın ve bir ağaç kovuğunun içinden çıkan hanımlar, Türklerin kozmik tasavvurlarının birer sembolü idi. Bu sembollerin gerçek hayattaki anlamı ise, tamamen farklı idi. Kanaatimizce, bu semboller, eski Türk toplumundaki iki büyük ve güçlü kabileyi temsil etmekteydi. Oğuz Kağan da bu iki kabileden birer eş almak suretiyle onların gücünü ve desteğini kazanmıştır. Nitekim bütün Türk hükümdarları da iktidarlarını ve askerî güçlerini artırabilmek için hep böyle yapmışlardır (Koca, 2011, s. 84). 
Dolayısıyla metinden hareketle anlatının şekillendiği toplumda hükümdarın yanı sıra ailesinin de kutsal bir kimlik taşıması gerekli görülmektedir yorumu yapılabilir. Anlatının bu kısmında kağanın dinî görevlerini yerine getiren, kut almış, aile sahibi biri olması gerektiği sonucuna varılabilir. Yine metinden anlaşıldığ 1 üzere kağan eşlerini severek almıştır. $\mathrm{Bu}$ da göstermektedir ki kağan duygusal özelliklere de sahiptir.

Eski Türk kültür ve geleneğinde kozmolojik unsurların ve tabiat unsurlarının büyük önemi vardır. Destandan hareketle Oğuz Kağan'ın çocuklarının isimlerinin Gün, Ay, Yıldız; Gök, Dağ, Deniz olması da Oğuz Kağan'ın cihan hâkimiyeti düşüncesinin bir göstergesi olarak yorumlanabilir. Nitekim Türk hükümdarları yer ile gök arasında kalan topraklara hâkim olma ülküsüne de sahiptir.

"Ondan sonra Oğuz Kağan büyük toy verdi. Çağırılan halk birbirine danışıp geldi. Oğuz Kağan kırk sıra kırk masa yaptırdı. Türlü aşlar, türlü şaraplar, tatlılar, kımızlar, yediler ve içtiler" (Banarlı, 1987, s. 18). Türk devletinde kanunların çıkarılması ve uygulanması, önemli kararların alınması, devlet başkanının seçilmesi gibi önemli siyasi faaliyetleri yerine getiren kurultay ve danışma kurullarının yanı sıra toy adı verilen toplantılar da Türk siyasi hayatında önemli bir yere sahipti. Toylar senenin belirli zamanlarında boy temsilcilerinin zorunlu katılımlarıyla gerçekleştirilir ve bu toplantılarda kurbanlar kesilir, dinî ve millî törenler yapılır, devlet ve millet meseleleri uzun uzadıya görüşülür ve sonunda karara bağlanırdı (Güney, 2012).

Oğuz Kağan'da hakanlığını ilan etmek için toyda beylerine şöyle seslenir (Banarlı, 1987, s. 18):

"Ben sizlere oldum Kağan,

Alalım yay, dahi kalkan

Talih bize olsun nişan

Bozkurt sesi olsun uran

Demir mızraklar bir orman

Avlakta yürüsün kulan

Daha deniz daha muran

Gün tuğ olsun, gök kurikan."

$\mathrm{Bu}$ sesleniş bir hükümdarın halkına büyük bir amaca hizmet için çağrısıdır. Bu amaç "Ben Uygurların kağanıyım ki, yerin dört bucağının kağan olsam gerektir” (Banarlı, 1987, s. 19) 
sözlerinden de anlaşılmaktadır. Ayrıca Oğuz Kağan lider olmak için gerekli sınavlardan geçmiş, aile kurmuş ve artık yeryüzünün dört bucağına hakan olması gerektiğini ferman, buyruk, yardım gibi anlamlarda kullanılan yarlıkla bildirmektedir.

Oğuz Kağan, iyi bir devlet adamı olarak savaşmadan önce uzlaşma yolunu tercih etmektedir. Nitekim Oğuz Kağan dört yöne haberci gönderir ve kendisine itaat edilmesini ister. "Sizlerden baş eğmenizi istemekteyim. Kim benim ağzıma bakarsa hediyelerini alıp onu dost tutarım. Kim ağzıma bakmazsa gazaba gelir, çeri çıkarıp düşman tutar, baskın yapıp onu astırır, yok ederim" (Banarl1, 1987, s. 19). Oğuz Kağan bu teklifine rıza gösterenleri himayesine alır ve onlarla dost olur, vergiye bağlar rıza göstermeyenlerin ise üzerine yürür. Orhun Abideleri’nde de Oğuz Kağan'ın bu yaklaşımına benzer bir yaklaşım şöyle ifade edilmiştir (Ergin, 2011, s. 9):

Üstte mavi gök, altta yağız yer kılındıkta, ikisi arasında insanoğlu kılınmış. İnsanoğlunun üzerine ecdadım Bumin Kağan, İstemi Kağan oturmuş. Oturarak Türk milletinin ilini töresini tutuvermiş, düzenleyivermiş. Dört taraf hep düşman imiş. Ordu sevk ederek dört taraftaki milleti hep almış, hep tâbi kılmış. Başlıya baş eğdirmiş, dizliye diz çöktürmüş.

Oğuz Kağan'ın mücadeleleri sırasında gök yeleli bir bir kurt kendisine eşlik eder ve yol gösterir. “Oğuz Kağan'ın çadırına güneş gibi bir 1ş1k girdi. O 1şıtan gök tüylü, gök yeleli, büyük bir erkek kurt çıktı... Oğuz Kağan çadırını dürdü gitti, gördü ki çerinin önünde gök tüylü, gök yeleli, büyük bir erkek kurt yürümektedir. O kurdun ardı sıra ordu yürümektedir” (Banarlı 1987, s. 19).

Türk destanlarında atla birlikte yer verilen en önemli unsurlardan biri olduğu düşünülen kurdun; türeyiş sağlayan kurt, kurtarıcı kurt, cetlerine yardım eden ruh ve kılavuz kurt olarak metinlerde yer aldığı görülmektedir. Kurt (bozkurt, gökkurt) Tanrı'nın tecelli ettiği varlıktır. Bu hâl Türk düşüncesinin Tanrı tasavvuruyla alakalı olup, onu somutlaştırma algısının bir tezahürüdür. Başka bir söyleyişle kurt, Tanrı'nın yeryüzüne inme ihtiyacı duyduğunda suretini tercih ettiği varlıktır. Balkaya (2015), kurt-ata kültü gereği insanların herhangi bir hayvan soyundan gelindiği inancı gereği kutlu bir hayvan olduğuna inanılan kurdun ilk ata olarak kabul edildiğini söylemektedir. Yine Türk kültüründe kurdun boz ve gök renkli olması da inanışlarla ilgilidir. Gök rengi, sonsuzluğu, türeyişi, emniyeti, huzuru, dostluğu, sadakati, temizliği, ruhaniliği temsil ettiği renkleri itibariyle de kurdun yardımcı olarak özel anlamlar taşıdığı görülmektedir. Balkaya (2015) halk anlatılarındaki yardımcı karakterlere ilişkin çalışmasından kurt, bilge kişi ve savaş̧̧ılar gibi yardımcı karakterlerden bahsetmiştir. Oğuz Kağan Destanı'nda 
bilgi yol danışman, yardımcı savaşçılar ve yol gösterici kurt motifleri görülmektedir. Bunlar aşağıda açıklanmıştır.

Türk menşe efsanelerinin temel kabulü; Tanrı'nın Türk milletinin hayat ve istikbali ile ilgilenen "ulu varlık" olduğu merkezindedir. Oğuz'a yol göstermesi bu bağlamda değerlendirilmelidir (Aslan, 2010).

Oğuz destanında, Oğuz Han’a zaman zaman kılavuzluk edip yol gösteren ve Tanrı tarafindan gönderilen kutsal kurttan söz açılırken, hep 'gök tüylü, gök yeleli’ deyimi de kullanılır. Burada kurda, 'gök’ sıfatının verilmesi, onun kutsallı̆ıını ve Tanrı ile ilgisini göstermeden başka bir mana taşımamalıdır. Sonraları, bu 'gök' sıfatı, ihtiyarlık ve tecrübeliliğin ifadesi ve karşılığı olarak kullanılmıştı (Ögel, 1993, s. 134).

Ayrıca eski Türk inanç sisteminde atalar ruhunun kurt kılığına girerek, kendilerine yardım edip yol gösterdiklerine inanılırdı. Bu inanç ve düşünce Türkler İslâm dinine girip İslâm dünyasına hâkim olduktan sonra da devam etmiştir. Konar-göçer hayat Türklere, coğrafya ve iklim hakkında son derece faydalı bilgiler kazandırmış ve onları bu hususta âdeta uzmanlaştırmıştır. Türkler arasında coğrafyayı ve iklimi iyi tanıyan yetenekli kılavuzlar yetişmiş ve bu kılavuzlar Türk beylerinin çıktıkları akın ve seferlerde onların bu faaliyetlerinin başarılı bir şekilde sonuçlanmasını sağlamışlardır. İşte Oğuz Kağan'a ve ordusuna kılavuzluk eden kurt, bu uzman kişilerden biridir (Koca, 2011).

Anlatıda ilerleyen safhalarda "Oğuz Kağan gene gök tüylü, gök yeleli erkek kurdu gördü. Bu kurt Oğuz Kağan’a dedi ki: "Şimdi (sen) çeri ile buradan atlan Oğuz! Atlanıp halkı beylerini götür. Ben sana, önden yürüyüp yol göstereceğim” (Banarl1, 2004, s. 19) ifadelerini görüyoruz. Anlatıda kurt Oğuz Kağan'a yol göstericilik yapmakta ve ona öğütler vermektedir. Dolayısıyla Oğuz Kağan'ın tek başına hareket etmediği, öğütlerine kulak verdiği, kutsal özelliklere sahip birilerinin olduğu söylenebilir. Kurttan türeyiş mitini akla getirerek yorum yapıldığında atalarının kurt olduğunu düşünen bir toplum hafizasının Oğuz Kağan'a kurdu kılavuz yapması doğal bir sonuçtur. Kurdun doğal bir gerçeklik olmadığı anlatının sembolik dilinde kurt olarak ifade edilen kutsal özelliği olduğuna inanılan atalar kültünün bir yansıması olduğu düşünülebilir. Yine Ergenekon'dan çıkışta kurdun kılavuzluğunu destanlaştıran bir toplumun aynı düşünceyle Oğuz Kağan'a danışman ve yol gösterici olarak kurdu seçmesi anlamlidir. 
Yine bu bilgilerden hareketle Oğuz Kağan Destanı'ndaki kağanın özelliklerinden birinin de nasihat dinlemek, başka bir ifadeyle danışarak hareket etmek olduğu söylenebilir.

Oğuz Kağan, İtil denen ırmağa geldi. İtil denen, büyük bir ırmaktır. Oğuz Kağan onu gördü. Dahi dedi ki: İtil'in surundan nasıl geçeriz? dedi. Çeride iyi bir bey vardı. Onun adı Uluğ Ordu Bey idi. Akıllı bir erdi. Gördü ki bu yerde çok delim dallar, çok delim ağaçlar (var). O ağaçları kesti. Ağaçlara yattı, geçti...Oğuz Kağan bir alaca aygır ata binerdi...Yolda bu aygır at gözden yitip kaçıp, gitti...Oğuz Kağan'ın atı Buz Dă̆ içine kaçıp gitti. Oğuz Kağan bundan çok acı çekti. Çeride bir büyük kahraman er bey vardı... O bey dağlara gitti. Yürüdü. Dokuz günden sonra Oğuz Kağan'a aygır atı getirdi... Oğuz Kağan'ın çerisinde akıllı, iyi bir becerikli kişi vardı. Onun adı Barmaklığ Çosun Bilig idi. Bu becerikli (usta) bir kağnı yaptı. Kağnı üstüne cansız malları koydu (Banarlı, 2004, s. 19-20).

Oğuz Kağan seferleri sırasında aşılması gereken birtakım engellerle karşılaşır ve beraberindeki iyi yetişmiş adamları sayesinde bu engelleri aşarak ilerlemeye devam eder. Görülmektedir ki Oğuz Kağan'ın beraberinde iyi yetişmiş ve tecrübeli kişiler bulunmaktadır.

Anlatının bu kısmından yöneticilerin önemli vasıflarından birinin de etraflarında bilgili, akıllı, kahraman insanları bulundurmaları ve bunlardan devlet yönetiminde yararlanmaları olduğu söylenebilir. Başka bir ifadeyle devlet adamı çevresindeki insanları seçme ve yönetmede becerikli olmalıdır. Metinden çıkarılabilecek bir diğer sonuç Oğuz Kağan'ın sevildiği yargısıdır. Çünkü bütün beyler Oğuz Kağan'a yardımcı olduktan sonra kağanın yüzü gülmektedir. Dolayısıyla yaptıklarıyla kağanı mutlu etmektedirler.

İşte bu yerin kağanı Masar denen bir kağandı. Oğuz Kağan onun üstüne atlandı. Çok yaman (bir) vuruşma oldu. Oğuz Kağan üstün geldi. Masar Kağan kaçtı. Oğuz onu bastı. Yurdunu aldı. Gitti. Onun dostları çok sevindi. Onun düşmanları çok kaygılandı. Oğuz Kağan yendi. Sayılamayacak nesneler, at sürüleri aldı (Banarlı, 1987, s. 20).

Oğuz Kağan, çıktı̆̆ı seferlerin hepsinden galibiyetle döner. Seferlerden toprak ve ganimet elde eder. Görülmektedir ki Oğuz Kağan, ordusu kuvvetli bir hakandır.

“Oğuz Kağan’ın yanında aksakallı, kır saçlı, uzun akıllı (tecrübeli) bir yaşlı kişi vardı. Anlayışlı, doğru bir erdi. Tüşimel (nazır, vekil, vezir) idi. Onun adı Uluğ Türük'dü” (Banarlı, 2004, s. 20). 
Yardımc1 (2007) eski Türklerde topluma manevi liderlik yapan, toplumu yönlendiren ve sözü dinlenen, ögüt verici lider kişilerin olduğunu; bu kişilerin aksakallı ifadesiyle belirlendiğini ve bu bilge tipin Türk destanlarında önemli olduğunu yazmıştır. Türk destanlarında kağanların yanlarında bilge vezirler bulundurduğunu ve verecekleri kararlarda bilgelere danışmaları bilgeliğe önem vermelerinden kaynaklandığını Oğuz kağan Destanı'nda da Oğuz'un akıl hocalarından Uluğ Türük'ün bilge tipinin iyi bir örneği olduğunu vurgulamıştır.

Oğuz Kağan Destanı'nda Oğuz'un yanında akıllı bilgili kişiler bulundurması, yine danışmanlığını yapan Uluğ Türük'ün akıllı, bilge, doğru, yaşlı biri olması yönetimde bu yeterliliklere sahip kişilerin olması düşüncesinin bir yansıması olduğu söylenebilir. Uluğ Türük yaşlı biridir ve Oğuz Kağan ona saygı göstermektedir. Dolayısıyla oğuz kağan büyüklerine sayg1 gösteren bir kişiliktir. Yine Uluğ Türük akıllı ve bilgedir. Oğuz Kağan da bilgili ve akıllı kişilere değer vermektedir. Başka bir ifadeyle devletini akıl ve bilgiyle idare etmektedir çıkarımı yapilabilir.

Uluğ Türük "Uykudan sonra düşte gördüğünü Oğuz Kağan’a bildirdi. Dahi dedi ki: "Ey Kağanım! Sana hayat hoş olsun. Ey Kağanım! Sana dirilik hoş olsun. Gök Tarı düşümde ne verdiyse gerçek olsun. (Tanrı) bütün dünyayı senin nesline verdirsin” (Banarlı, 1987, s. 20).

Tarih boyunca iktidarın meşrulaştırılmasında siyasi erki elinde bulunduranlar çeşitli vasıtaları kullanmışlardır. Rüya da bu anlamda kullanılan en önemli vasıtalardan biridir (Timur, 2004). İslamiyet öncesi Türk toplumlarında da rüya güvenilir bir bilgi kaynağıdır. Kurucu ve siyasi mesajlar taşıyan rüyaların etkileri daha derin ve güçlü olmuştur. Bu yolla manevi bir güç kazanarak iktidarını halk nazarında meşrulaştırma geleneği Türklerde eski devirlerden beri bulunmaktadır. Rüya içerisinde kullanılan semboller ise rastgele olmayıp siyasi güç iddiasında olanların erkini ya da "kut" u Tanrı'dan aldıklarını çok sembolik ve açık bir şekilde hedef kitleye anlatmaktadır (Temizkan ve Aktaş, 2012).

“Oğuz Kağan Uluğ Türük'ün sözünü beğendi. Öğüdünü dinledi” (Banarl1, 2004, s. 20). Oğuz Kağan'ın veziri Uluğ Türk bir gün rüyasında bir altın yay ve üç gümüş ok görür. Altın yay gün doğusundan gün batısına kadar uzanır. Üç gümüş ok da kuzeye doğru gitmektedir. Uluğ Türk bu rüyayı Oğuz Kağan'a anlatır. Oğuz Kağan Uluğ Türk'ün öğüdünü dinler ve ertesi gün büyük ve küçük oğullarını çağırtır. Destanda görüldüğü üzere cihan hâkimiyeti düşüncesi her firsatta ifade edilmektedir. Destandaki "bütün dünyayı senin nesline versin." ifadesi de bu düşüncenin farklı bir şekilde dile getirilmesidir. 
Rüyanın anlatılmasından sonra Oğuz Kağan çocuklarını yanına çağırır ve bir av düzenler.

Ondan sonra üç (tanesi) tan yönüne vardırlar. Üç (tanesi) de batı yönüne vardılar. Gün, Ay, yıldız, çok avlar, çok kuşlar avladıktan sonra, yolda bir altın yay buldular. Aldılar, (babalarına verdiler.) Oğuz Kağan sevindi, güldü, dahi yayı üçe böldü. Ey büyük oğullarım. Yay sizlerin olsun. Yay gibi okları göğe kadar atın (Banarlı, 2004, s. 20).

Oğuz Kağan'ın Gün, Ay, Yıldız’1 doğuya göndermesi ve bu oğullarının altın yayı bulmaları doğuyu, batıya; yayı da oka üstün tutuğunun göstergesidir. Türk devlet geleneğinde esas halk kitlelerinin ve devlet merkezinin olduğu taraf doğudur. Dolayısıyla devlet merkezi yayı bulan büyük oğullara verilecektir. Çünkü tarih boyunca yay hâkimiyet sembolü olarak kullanılmıştır (Onay, 2013). Türklerde başlıca hükümdarlık sembolleri hakan çadırı (otağ), taht (örgin), tuğ davul ve sorguçtur. Yay hâkimiyeti ve Tanrı iradesini temsil eden hakanı, ok ise kavmi sembolize eder. Okun yaya bağımlı olması tabiiyeti ve bütünlüğü ifade eder. Ok ve yayın birleşmesi cihan hâkimiyetinin gerçekleştirileceği anlamını taşır (Güney, 2002).

Göksu (2010) çalışmasında okun Türklerde tabiiyet ve devlet sembolü olarak kullanıldığı, yayın ise metbuluk ve hâkimiyet sembolü olarak kullanıldığını ifade etmiştir. Çalışmasının sonunda da "Ok ve yayın, Türk devlet geleneği ve hâkimiyet anlayışı içerisinde bir sembol olarak kullanılmasına dair bilgiler, (....) destanlar çağına kadar uzanır. Oğuz Kağan Destanı'nda Oğuz Kağan, oğulları arasındaki “orun” yani siyasî ve içtimaî mevkii düzenlerken "yay"1 metbûluk, “ok"u ise tâbiiyyet sembolü olarak" (Göksu, 2010, s. 1005) belirlediğini vurgulamıştır.

“Gök, Dağ, Deniz, çok avlar, çok kuşlar avladıktan sonra yolda üç gümüş ok buldular. Aldılar, babalarına verdiler. Oğuz Kağan sevindi, güldü, dahi okları üçe böldü. Dahi Söyledi ki: Ey küçük oğullarım. Oklar sizlerin olsun. Yay oku attı. Sizler oklar gibi olun” (Banarlı, 2004, s. 20). Metne göre Oğuz Kağan batıya gönderdiği küçük oğullarına ülkesinin batısını vermiş ve onlara ok gibi doğru olmalarını öğütlemiştir.

Daha sonra beylerini ve halkını toplar. Bu kurultayda Oğuz Kağan yurdunu oğulları arasında bölüştürür Oğuz Kağan böylelikle kendisinden sonraki yönetim sistemini de belirlemiş olur. Devlet ikili yönetim sistemine tabi olacaktır. Doğu’yu Bozok’a (Gün, Ay, Yıldız) ve 
Batı’yı da Üçok'a (Gök, Dağ, Deniz) bırakır. Bu ikili sistemde hâkimiyet ve üstünlük Bozok koluna bırakılmıştır.

Hâkimiyetin ve üstünlüğün Bozok koluna verilmesi, bu kola mensup oğulların büyük oğul olmalarından değil, annelerinin "Ulu Hatun" ve kendilerinin de uzayı (gün, ay, yıldız) temsil etmelerinden ileri gelmiştir. Çünkü Türklerde, hükümdarın "Ulu Hatun" olmayan eşlerinden doğan oğulları, ne kadar yetenekli olurlarsa olsunlar, taht üzerinde bir hak iddia edemezlerdi (Koca, 2011, s. 94).

Ok ve yayın birleşmesi cihan hâkimiyetinin gerçekleştirileceği anlamını taşır. Otağ hakanlığı temsil eden ve güvenlik bakımından önem arz eden bir semboldür. Otağın yıkılması hükümdarlığa son verildiği anlamına gelir (Güney, 2002).

Oğuz Kağan oğullarına yurdu paylaştırdıktan sonra şöyle hitap eder: "Ey oğullarım! Ben çok yaşadım. Ben çok savaşlar gördüm. Çıda ile çok ok attım. Aygır ile çok yürüdüm. Düşmanları ağlattım. Dostlarımı ben güldürdüm. Gök Tanrı'ya (borcumu) ödedim. Sizlere (de) yurdumu veriyorum" (Banarlı, 2004, s. 21). Bu ifadeler destanın özeti mahiyetindedir. Oğuz Kağan uzun bir hükümranlık sürmüştür. Çok savaşlara katılmış, bu savaşlarda kendisi de mücadele etmiş bir komutandır. At üstünde çok yol almıştır ve fethettiği topraklar oldukça fazladır. Düşmanlarını mağlup etmiş, dostlarını ise yardımcı olmuştur. Oğuz Kağan bunların hepsini Tanrı'ya olan borcunu ödemek için yapmıştır. Çünkü Türklerde kağanlık yani "kut" Tanrı vergisidir. Ve bir Türk hakanı erki müddetince "kut"un sorumluluğunu yerine getirmekle yükümlüdür. Bayat (2006) Türk devlet sisteminde kağanlık kurmanın Tanrı borcu fikrinin poetik bir ifadesi olduğunu belirtmiştir. Türk devlet anlayışında devletin atalardan kalmış bir miras olduğu inancı bulunduğunu da söylemiştir. Cevizci (2015) Fârâbî'nin yönetici ve devlet anlayışında ideal toplum ve devletin ancak hakikat bilgisiyle tesis edilebileceği, Tanrı ile evren ilişkisini bilen kişilerin ideal toplumu ve devleti oluşturacağını, bunu da filozoflar ve peygamberlerin yapabildiği düşüncesinde olduğunu söylemiştir. Fârâbî’ye göre yönetici toplumu ve devleti nasıl düzenleyeceğini Etkin Akıl ile kurulan temasla öğrenmektedir. Etkin Akı1 ise Batılı filozoflar tarafından Tanrı olarak nitelendirilmektedir fakat Fârâbî'nin Etkin Akla yüklediği anlam İslam şeraitine uygun görülmektedir. Burada dikkat çeken husus Fârâbî’nin hakikat bilgisine vurgu yapmasıdır. Onun hakikat bilgisine vurgu yapması Michel Foucault'un iktidar kavramını açıklarken iktidar bilgi ilişkisine vurgu yapmasını akla getirmektedir (Çelebi, 2013). "Bilgi, iktidar ya da güç ilişkilerinin içerisinde yer almaktadır. Güç kullanımına bilgi aygıtlarının üretimi eşlik eder veya denk düşer. Güç kullanımı bilgiyi gerektirir. Bilgi yansız ya 
da nesnel olmayıp, daha ziyade iktidar ilişkilerinin bir ürünüdür. Bilgi, kendi varlık ya da imkân koşullarının iktidar ilişkilerini içermesi anlamında, politiktir" (West, 1998, s. 236'dan akt. Çelebi, 2013, s. 516 ). Kut ile kutsallığı ve Tanrı tarafından sorumluluk yüklenen Oğuz Kağan kişiliği bu bağlamda değerlendirildiğine bilgi sahibi olduğu söylenebilir.

\section{Sonuç}

İlk çağlardan günümüze kadar devam eden süreçte Türk devlet yöneticiliğinde yer alan hükümdarların birtakım niteliklere sahip olması beklenmiştir. Türk devlet geleneğinde sahip olacağı niteliklerin getirisi olarak yerine getirmesi gereken önemli görevleri vardır. Bir Türk hakanı/hükümdarı halkını eğitmekle, milletini, töreyi ve devleti düzene koymakla, devletini ve milletini derleyip toparlamakla, halkını ve nüfusunu çoğaltmakla, açları doyurup, fakirleri giydirmekle, at ve elbise dağıtmakla, milletine altın, gümüş ve değerli şeyler kazandırmakla, devlet ve milleti için kazanmakla, halkını iskân ettirmekle, asayiş ve güvenliği sağlamakla, devleti ve milleti adaletle idare etmekle ve halkına iş ve çalışma imkânı vermekle yükümlüdür (Taneri, 1997; Güney, 2002).

Oğuz Kağan Destanı'ndaki hakan/hükümdar tasviri incelendiğinde hükümdarın asil bir soydan geldiği ve Tanrı tarafından kendisine "kut" yani yöneticilik yetkisi verildiği görülmektedir. Oğuz Kağan Destanı mitolojik unsurlarla örülü bir metin olması nedeniyle tabiata ve varlıklara ait unsurların kahramanın tasvirinde kullanıldığı görülmektedir. Oğuz Kağan'a atfedilen hayvanlara ait özellikler onun gücünün simgesi olarak kabul edilebilir. Oğuz Kağan'ın mitolojik unsurlarla güçlendirilmiş kağanlığı kut kültüne dayanmaktadır. Tanrı adına ülkeyi yönetme sorumluluğu bilinci anlatıda görülmektedir.

Oğuz Kağan, atlı-göçebe hayat tarzının ve kültürünün ideal insan tipini temsil eder. Yaşadığı coğrafya düşünüldüğünde, o coğrafyanın şartlarına uygun yetiştirilmiş cesur bir yiğittir, aynı zamanda savaşçıdır. Hükümdar olmak için verdiği mücadeleyi zekâsını ve aklını kullanarak kazanmıştır. Oğuz Kağan ormandaki yabani hayvanı avlarken zekâsını kullanmıştır. Yine zalimlerin gerekli şekilde cezalandırılması ve mazlumların korunması vurgulanır. Oğuz Kağan halkına zulmeden canavar ile savaşır ve onu alt eder.

Destanda devletin ordusunun güçlü olması ve hükümdarın ordusunu ödüllendirmesine değinilmektedir. Oğuz Kağan, ordusu kuvvetli bir hakandır. Bu sayede girdiği bu ve bunun gibi birçok savaştan galibiyetle çıkmaktadır. Ayrıca işi liyakat sahibi olana vermek de metinde vurgulanmaktadır. Yine Oğuz Kağan liyakat sahibi kişilere fikir danışmayı tercih etmektedir. 
Uluğ Türk ve ordusundaki beylere danışmayı ihmal etmez ve onların düşüncelerine önem vermektedir.

Türk devlet yöneticilerinin cihan hâkimiyeti ülküsüne sahip olması metinde vurgulanır. Oğuz Kağan'ın yaptığı evlilikler, çocuklarına verdiği isimler sembolik olarak cihan hâkimiyeti ülküsünü temsil etmektedir. Ayrıca Oğuz Kağan yaptığı fetihlerle de bu ülküyü gerçekleştirir. Eski Türklerin ve Oğuzların fetihlerini destanî bir şekilde anlatan Oğuz-Name'ye göre ilk cihan hâkimiyeti Oğuz Kağan tarafından gerçekleştirilmiştir (Turan, 1998).

Oğuz Kağan cömert bir hükümdardır. Savaşlardan elde edilen ganimeti asker ve halkına dağıtır. Ayrıca büyük toylar düzenleyerek halkını doyurur. Oğuz Kağan, iyi bir devlet adamı olarak savaşmadan önce uzlaşma yolunu tercih etmektedir. Hiddetle hareket etmemektedir.

Oğuz Kağan Destanı bize bir hükümdarın sahip olması gereken özellikler açısından bilgi vermektedir. Oğuz Kağan Destanı'nın kahramanı Oğuz Kağan bozkır hayatına uygun bir alp tipi sergilemektedir. Hem bilgilidir, hem güçlüdür, hem savaşçıdır, hem de siyaset bilgisiyle devletini en iyi şekilde idare ederek hem halkını mutlu eder hem de ülkesinin sınırlarını genişletir.

Türklerde devlet yönetimi ve hükümdarlık bir sanat olarak benimsenmiş ve ilk çağlardan itibaren yöneticilerinin kültürlü, erdemli ve cesur yetişmesine önem verilmiştir. Bir hükümdarın bu niteliklere sahip olması devlet yönetimine ait birer ilke gibi benimsenmiştir. Bahsi geçen vasıflar açısından yetersiz olan devlet yöneticilerinin yönetimdeki olumsuz etkileri ac1 tecrübeler bırakmıştır (Taneri, 1997).

Türk devlet ve hâkimiyet anlayışı dikkate alındığında Oğuz Kağan Destanı'ndaki hükümdar tipinin sahip olduğu özelliklerin aslında bir yöneticinin sahip olması gereken özellikler olduğu ve Oğuz Kağan'ın bu özellikleri taşıdığı söylenebilir.

Oğuz Kağan Destanı farklı inceleme (söylem çözümlemesi, gösterge bilimsel olarak inceleme, içerik analizi $v b$.) yöntemleriyle ele alınabilir. Ayrıca Oğuz Kağan Destanı'nda ortaya konulmaya çalışılan hükümdar tasarımı Türk kültür tarihî açısından değer taşıyan başka eserlerdeki hükümdar anlayışı ile karşılaştırılabilir. Yine Oğuz Kağan Destanı'nda ortaya konulan hükümdar anlayışı günümüzdeki yönetici algısıyla ilişkisinin incelenebileceği çalışmalar da yapılabilir. 


\section{Kaynaklar}

Aksoy, N. D. (2000). Oğuz Kağan Destanı ve dini motifler. Firat Üniversitesi Illahiyat Fakültesi Dergisi.1(5), 244-252.

Akyüz, H. (2002). Kutadgu Bilig'de sosyo pedagojik ve siyasal söylem. Erzurum: Eser Ofset.

Aslan, N. (2010). Kurt motifinin Türk menşe efsanelerindeki anlamı üzerine. Millî Folklor, 22(87), 72-77.

Aydemir, A. (2010). Ötüken ve Ötüken adı üzerine. Türk Dünyası Araştırmaları, 187, 197-222.

Balkaya, A. (2015). Halk anlatılarında kahramanın yardımcıları. İstanbul: Fenomen Yayınc1lik.

Banarlı, N. S. (1987). Resimli Türk edebiyatı tarihi I-II. İstanbul: Millî Eğitim Bakanlığ1 Yayınları.

Banarlı, N. S. (2004). Resimli Türk edebiyâtı târihi. (I. Cilt). İstanbul: Milli Eğitim Bakanlığı Yayınları.

Bars, M. E. (2008). Oğuz Kağan Destanı üzerine yapılan çalışmalar. Turkish Studies, 3(4), 224240.

Bayat, F. (2009). Mitolojik zıtlık paradigmasında baba - oğul mücadelesi. Uluslararası Sosyal Araştırmalar Dergisi, 2(6), 63-70.

Bayat, F. (2002). Oğuz Kağan Destanı üzerine yeni düşünceler. Türkler. Ed. Hasan Celal Güzel vd. C. 3. İstanbul: Yeni Türkiye Yay. 520-526.

Bayat, F. (2006). Oğuz destan dünyası. Ankara: Ötüken Neşriyat.

Bayat, F. (2009). Mitolojik zıtlık paradigmasında baba oğul mücadelesi. Uluslararası Sosyal Araştırmalar Dergisi. 2 (6), 63-70.

Bogenbayev, N., Calmırza, A. (2014). Eski Türk dünya görüşündeki "kut" ve "karga" kavramları. Millî Folklor, 103, 69-79.

Cevizci, A. (2015). Felsefe tarihi. (1. Bask1), İstanbul: Say Yayınlar1.

Çelebi, V. (2013). Michel Foucault'da bilgi, iktidar ve özne ilişkisi. Sosyal ve Beşeri Bilimler Dergisi. 5(1), 512-523.

Çiftçi, F. (2013). Axel Olrik'in epik yasaları 1şığında Oğuz Kağan Destanı'na bir bakış. Turkish Studies - International Periodical For The Languages, Literature and History of Turkish or Turkic 8(4), 515-524

Çoruhlu, Y. (2002). Türk mitolojisinin anahatları. İstanbul: Kabalcı Yayınevi.

Divitçioğlu, S. (1994). Oğuz'dan Selçukluya, İstanbul: Eren Yayıncılık.

Duymaz, A. (2007). Oğuz Kağan Destanı'ndan Dede Korkut Kitabı'na kahramanların beden tasvirlerinin sembolik anlamları üzerine değerlendirmeler. Milli Folklor. 19(76), 50-58. 
Elçin, Ş. (1986). Halk edebiyatına giriş, Ankara: Akçağ Yayınları.

Ercilasun, A. B. (2002). Oğuz Kağan Destanı üzerine bazı düşünceler. İslamiyet Öncesi Türk Destanları (Haz. Saim Sakaoğlu -Ali Duymaz), İstanbul: Ötüken Neşriyat.

Ergin, M. (2011). Orhun Abideleri. İstanbul: Boğaziçi Yayınları.

Göksu, E. (2010). Ok ve yayın Türk devlet geleneği ve hâkimiyet anlayışındaki yeri. Turkish Studies International Periodical For the Languages, Literature and History of Turkish or Turkic, 5(2), 986- 1011.

Gömeç, S. (2003). Oguz Kagan'ın kimliği, Oguzlar ve Oguz Kagan destanları üzerine bir-iki söz. Ankara Üniversitesi Çağdaş Türklük Araştırmaları Sempozyumunda sunulmuş.

Gömeç, S. (2006). Türk kültürünün ana hatları. (1. Bask1), Ankara: Akçağ Yayınları.

Güney, A. (2002). Türk siyasal kültüründe devlet anlayışı. Yayımlanmamış doktora tezi. Süleyman Demirel Üniversitesi, Isparta.

Güven, M. (2009). Oğuz Kağan Destanı’nda hayvanlar. Milli Folklor, 15(57), 82 - 91.

İnan, A. (1968). Türk destanlarına genel bir baklş. Makaleler ve incelemeler. Ankara: Yeni Türkiye Yayınları.

İnan, A. (1970). Yusuf Has Hâcib ve eseri Kutadgu Bilig üzerine notlar. Türk Kültürü, 98, 117.

Kabakl1, A. (2006). Türk edebiyatı (2. Cilt), (Gözden geçirilmiş 13. Bask1). İstanbul: Türk Edebiyatı Vakfı Yayınları.

Kadaşeva, K. (1996). Kazak Medeniyeti'ndeki semboller. Nevruz ve Renkler. (Haz. Sadik Tural ve Elmas Kılıç). Ankara: AKM Yay.

Kaplan, M. (1996). Oğuz Kağan-Oğuz Han Destanı. Türk Edebiyatı Üzerinde Araştırmalar 3 Tip Tahlilleri. İstanbul.

Kaplan, M. (2002) Oğuz-Kagan - Oğuz Han Destanı. Türkler, (III. Cilt, s.512.) içinde, Ankara:

Kaşgarlı Mahmut. (1991). Divanü Lügat-it Türk, (Çev: Besim Atalay). Anakara: Türk Dil Kurumu Yayını.

Kazmaz, S. (2000). Hukuk ve devlet yönetimi açısından Kutadgu Bilig. Ankara: Takav Matbaacil1k.

Koca, S. (2002). Eski Türklerde devlet geleneği ve teşkilat1, Türkler, c. 2, Yeni Türkiye Yayınları.

Koca, S. (2011). İdeal bir Türk hükümdarı ve başkomutanı olarak Oğuz Kağan (Oğuz Kağan Destanı'nın Türk kültür tarihi bakımından değerlendirilmesi) Büyük Selçuklu Devletinden Türkiye Selçuklu Devletine Mehmet Altay Köymen Armağanı. Selçuk Üniversitesi Türkiyat Araştırmaları Enstitüsü Yayınları: 5

Koçak, K. (2011). İslamiyet'ten önceki Türk devlet geleneklerine göre tahta çıkma töreni ve yöntemleri. Gümüşhane Üniversitesi Sosyal Bilimler Elektronik Dergisi, 4, 101-117. 
Küçük, S. (2010). Eski Türk kültüründe renk kavramı. Bilig, 54, 185-210.

Oğuz, Ö. M. (2004). Destan tanımı ve eski Türk destanları. Milli Folklor, 62, 5-7.

Onay, İ. (2013). Türk kültür tarihi bakımından Oğuz Kağan destanı ve önemi. Türkiye Sosyal Araştırmalar Dergisi, 171, 29-44.

Ögel, B. (1982). Türklerde devlet anlayışı. Ankara. Başbakanlık Basımevi.

Ögel, B. (1993). Türk mitolojisi (Kaynakları ve Açıklamaları Ille Destanlar), I. Cilt. Ankara: Türk Tarih Kurumu Yayınları.

Özarslan, M. (1998). Oğuz Kağan Destanı'nda dinî, tarihî, tabiatüstü ve beşeri unsurlar. Folkloristik: Prof. Dr. Dursun Ylldırım Armağanı, (Haz. Metin ÖzarslanÖzkul Çobanoğlu), Türkiye Diyanet Vakfı Matbaası, Ankara, 424-438.

Özkul, Ç. (1996). Lord Raglan'ın batı halk kahraman kalıbı açısından Oğuz Kağan ve Er Töştük destan kahramanlarına bir bakış. Folkloristik: Prof. Dr. Umay Günay Armağanı (Ed. Çobanoğlu, Ö., Özarslan, M.) Ankara: Feryal Matbaacılık.

Öztürk, A. (1980). Çağlar içinde Türk destanları. (Birinci Baskı). Emek Matbaacılık.

Roux, J. P. (1999). Eski ve Orta Çağda Altay Türklerinde ölüm (Çev. Aykut Kazancigil), İstanbul: Kabalcı Yayınevi.

Sepetçioğlu, M. N. (1972). Türk destanları. (Birinci Baskı). Toker Yayınları.

Sepetçioğlu, N. (1995). Karşılaştırmalı Türk destanları. İstanbul: Akran Yayınları.

Sertkaya, O. F. (1995). Oğuz Kağan destanı üzerine bazı mülahazalar. Türk Dili Araştırmaları Ylllı̆̆ı-Belleten 1992, 9-27.

Taneri, A. (1997). Türk devlet geleneği. Ankara: Milli Eğitim Bakanlığı Yayınları.

Temizkan, A. ve Aktaş, E. (2012). Türk devlet geleneğinde iktidarın meşrulaştırılmasında rüyanın kullanımı. Journal of Black Sea Studies, 9(33), 13-22.

Timur, T. (2004). Kurucu efsaneler ve devlet, Osmanlı Devleti'nin Kuruluşu Efsaneler ve Gerçekler, Panel Bildirileri (ed. Suavi Aydın vd.), 35-46.

Tuğral, O. (2008). Kutadgu Bilig ve Siyasetname'de devlet anlayışı. Yayımlanmamış yüksek lisans tezi, Niğde Üniversitesi Sosyal Bilimler Enstitüsü, Niğde.

Turan, O. (1998). Türk cihan hâkimiyeti mefkûresi tarihi, C I. İstanbul: Boğaziçi Yayınları.

Yardımc1, M. (2007). Türk destanlarında tipler ve motifler- destanlar. Ankara: Ürün Yayınları.

Yılbır, S. (2006). Türk destanlarında inanç ve inanışlar. Yayımlanmamış yüksek lisans tezi, Sakarya Üniversitesi Sosyal Bilimler Enstitüsü, Sakarya. 